\title{
First-Line Nurse Administrators in Academe: How are They Prepared, What Do They Do, and Will They Stay in their Jobs?
}

Joy C. Princeton

University of Utah

Timothy M. Gaspar

Cleveland State University, t.gaspar@csuohio.edu

Follow this and additional works at: https://engagedscholarship.csuohio.edu/nurs_facpub

Part of the Nursing Commons

How does access to this work benefit you? Let us know!

Publisher's Statement

NOTICE: this is the author's version of a work that was accepted for publication in Journal of Professional Nursing. Changes resulting from the publishing process, such as peer review, editing, corrections, structural formatting, and other quality control mechanisms may not be reflected in this document. Changes may have been made to this work since it was submitted for publication. A definitive version was subsequently published in Journal of Professional Nursing, 7,2, (1991) DOI\#10.1016/8755-7223(91)90091-X

\section{Recommended Citation}

Princeton, J. C., \& Gaspar, T. M.First-line nurse administrators in academe: How are they prepared, what do they do, and will they stay in their jobs? Journal of Professional Nursing, 7(2), 79-87. doi:10.1016/ 8755-7223(91)90091-X 


\title{
First-Line Nurse Administrators in Academe: How Are They Prepared, What Do They Do, and Will They Stay in Their Jobs?
}

\author{
Joy C. Princeton, PhD, RN, FAAN* and Timothy M. Gaspar, PhD, RN
}

This article examines the role characteristics, responslbilities, and anticipated career patterns of first-line nurse administrators employed in university-based nursing education programs throughout the nation. First-line administration is the first level on the administrative ladder, and these administrators are most frequently entitled department chairpersons; division, program, and level directors; or coordinators. This was an exploratory and descriptive research project, and the questions addressed were (1) How are first-line nurse administrators in academe formally educated and informally prepared for their administrative role? (2) What are the administrative competencles important for this administrative role? (3) What strains, conflicts, and work overload are associated with the first-line administrative role, and what strategles are used to cope? (4) What do these administrators anticipate as a career pattern in administration based on their experiences as first-line administrators? Fifty-six first-line nurse administrators were interviewed from $\mathbf{4 2}$ schools of nursing that offer both bachelor's degree and graduate nursing programs. Data indicated that one third of the study participants completed graduate level courses in administration, and the majority had worked with administrative mentors. They ranked having character and Integrity as their most important competency, which was defined as being trusted by faculty, other administrators, and students. Settling priorities for their administrative work caused them their greatest strain, and work overload was most predominant. Role conflict was present consistently as they attempted to meet the traditional triad of faculty responsibilities (research and scholarship, teaching, service) plus administrative duties. Numerous time-management strategies were used to cope, but nonetheless, one half will not continue In an administration career pathway. Implications for academic nurse administrators are cited. (Index words: Academic administration; First-line administration; Role conflict). J Prof Nurs 7:79-87, 1991. Copyright (C) 1991 by W.B. Saunders Company

\begin{abstract}
A FAMILIAR ADAGE in academe claims that the strength of a university and its constituent units is directly proportional to the strength, vitality, scholarship, and teaching achievements of the faculty. Academicians also recognize that effective, wellprepared, and competent administrators are needed at all levels, including chairpersons at the first administrative level to facilitate and promote faculty efforts.

This study investigated the role of first-line administrators in nursing schools throughout the nation by examining the role characteristics, responsibilities, and anticipated career patterns of nurses who held these positions. For the purpose of this study, firstline administrators were defined as nurses who held administrative positions which, in the organizational hierarchy, were placed between the faculty and midto top-level administration. They most frequently have the title of department chairpersons; or division, program, or level director; or coordinator.
\end{abstract}

\section{What Do We Know About First-Line Academlc Administrators?}

Two main issues predominate in the literature. The first issue addresses the need to educate people formally for the first-line administrative role, as well as

*Professor and Director, Social and Behavioral Systems in Nursing Division, University of Utah College of Nursing, Salt Lake City.

†Associate Professor, Department of Nursing, South Dakota State University, Brookings. 
the need for more informal approaches such as onthe-job training and mentorship programs.

The other issue focuses on role-related responsibilities and the competencies needed to fulfill the role. Inherent in this issue are concerns related to role stresses and strains, conflicts, work overload, and ultimately, the degree to which the administrator is satisfied with the job (Carpenter, 1989; Fain, 1987; George \& Coudret, 1986; Holcomb, 1988; Hoy \& Miskel, 1987; Kennerly, 1989).

\section{EDUCATION AND TRAINING}

The need to formally educate and prepare top-level administrators of university-based nursing schools, the deans and directors, has received considerable attention over the years (Arminger, 1976; Frank, 1986; George, 1981; George \& Deets, 1983; Hall, McKay, \& Mitsunaga, 1971; Hall, Mitsunaga, \& de Tornyay, 1981; Jarratt, 1975; Johnson, 1983; Zehr, 1974). Research and subsequent publications specifically on the educational preparation, role, and responsibilities of first-line nurse administrators have been extremely limited. For example, there is one publication on the nursing department chairperson in liberal arts colleges that was published by Bergeron (1963), and one doctoral dissertation on the topic completed by Ort in 1977. It is interesting to note, however, that the vital role of the head nurse, the first-line administrator in hospital and other nursing services departments, has been long-recognized and is well documented in the literature.

\section{The need to formally educate and prepare top-level administrators ... has received considerable attention ...}

Baker (1979) defined the academic chairperson as a middle manager; however, her description was indeed the traditional one used by management scholars for first-line administrators. She described this position in nursing schools (p. 147) as the "critical link in the chain of command." Her research focused on the role conflict these administrators perceived as they worked to fulfill their faculty-related responsibilitiesresearch and scholarship, teaching, and service-in addition to their administrative work. Baker's work (1979, 1981) emphasized the importance of preparing nurses for first-line academic administration.
Nonnursing literature contains more than 60 journal articles, approximately 50 doctoral dissertations, and several books and monographs have been written on the chairperson's job-related tasks. Scholars in educational administration, however, claim that little is known about first-line administrators as persons, their administrative preparation, or the competencies they need to fulfill the position (Dill \& Fullagar, 1987; Hammons, 1984; Jennerich, 1981; Schein, 1987); even less is known about these administrators in professional schools (Baker, 1979).

There are a few reports of training programs for first-line academic administrators, including the University of Utah Department Training Program, the Kellogg Foundation Program, the American Council on Education Program, the Western Interstate Commission of Higher Education Departmental Chairman Program, and the national conferences for academic chairpersons sponsored by the Kansas State University Division of Continuing Education (Cashin \& Akihiro, 1986; Ehrle, 1975; Monson, 1972; Waggman, 1984). Although Hawkins (1980), a nurse, described the mentorship she received to prepare her for a toplevel decanal role, there are no nursing reports on training programs for first-line nurse administrators similar to those in other disciplines.

In 1968, McKeachie wrote his seminal "Memo to New Department Chairmen," in which he stated

although the department chairmen in most colleges and universities are key individuals in determining the educational success of the institution, they are generally ill prepared, inadequately supported, and more to be pitied than censured. In many departments, the attitude of the faculty toward a colleague who accepts the department chairmanship is much like that of nuns' toward a sister who moves into a house of prostitution.

More recently others have claimed that most first-line administrators in universities are chosen for their personal characteristics and teaching and scholarly competencies, not for their educational preparation in administration (Falk, 1979; Scott, 1981; Tucker, 1984) in keeping with the myth that "yesterday's good professor is today's good chairman" (Ehrle, 1975). These claims beg the question about the criteria used in nursing schools for selecting chairpersons.

\section{ROLE-RELATED COMPETENCIES}

Branch (1985) discusses 14 nonnursing doctoral dissertations that dealt directly with the identification and clarification of the roles and responsibilities of chairpersons who work as first-line administrators. 
She concluded that there are basically 5 categories and 44 activities with which chairpersons are involved, all of which are nearly identical to the activities cited by Smith (1972) 12 years previously. The 5 caregories were general administration, student issues, budget, faculty, and curriculum and instruction.

There are two schools of thought regarding a common set of administrative competencies first-line administrators need to fulfill their job-related responsibilities successfully. On the one side Jennerich (1981) argues most persuasively (p. 54) that "unequivocally . . . there is a universal set of competencies that all chairpersons consider necessary for their jobs," regardless of their discipline. Conversely, others contend that the first-line administrative role and associated competencies have discipline-based distinctiveness if the academic discipline is evaluated and categorized according to three dimensions of subject matter: (1) the degree to which a paradigm exists; (2) the degree of concern with application; and (3) the degree of orientation toward life systems. Biglan (1973) developed the three-dimensional model, and he argued that the nursing discipline has all three dimensions; thus, the competencies required of the first-line nurse administrator are distinct to nursing.

First-line administrators in nursing, like in other disciplines, are in the nebulous and difficult position of being both faculty and administrator, but belonging completely to neither group. Some of these nurses may view themselves basically as administrators, while orhers see themselves as full-fledged faculty and scholars (Scott, 1981). It is not unusual for the new administrator, who previously served as a faculty member, to find that his or her source of identification as a scholar and teacher is eroded; it may take some time to develop an administrator identity (Skoheim, 1981).

Several academic administrators who are not nurses have addressed the question of why first-line administrative positions are not valued by faculty. To illustrate, Heimler (1967) argued that these administrators do not have a long-term commitment to their positions because they perceive their role as lower status than that of a researcher and scholar. Additionally, these administrators see their fellow faculty having time to teach and publish (Dilly, 1972, p. 29) "because we (administrators) have taken on the odious and unrewarding management function that they (the faculty) might be free." Furthermore, according to Booth (1972), this level of administration is viewed as a "career drag" rather than a career opportunity. The claim is also made that first-line administrators who continue to carry out all their customary research and scholarship, teaching, and service activities do so at the expense of their administrative tasks. Thus, the administrarive job becomes a chore, and the challenges and knowledge base related to leadership and organizational administration are never appreciated, learned, or actualized (Tucker, 1984); hence, the job is not valued. Hammons (1984) concluded from his research that there are five areas of frustration that potentially lead first-line administrators to resign: inadequate role definition: lack of time to fulfill responsibilities, monetary constraints, distorted communications, and administrative inefficiencies of higher level administrators.

\section{First-line administrators in nursing . ... are in the nebulous and difficult position of being both faculty and administrator, but belonging completely to neither group.}

In relation to the role of the first-time academic administrator, the themes that prevail in the literature are the strains, stresses, conflicts, and work overload inherent in the role. Role theory, therefore, was useful to conceptualize the research questions that directed the study.

\section{A NURSING PERSPECTIVE}

An exploratory and descriptive survey was conducted using a telephone interview schedule, mailed questionnaires, and an adapted validated instrument to answer the following questions in relation to firstline nurse administrators in academe:

1. How are they educated, both formally and informally, and otherwise prepared and oriented for their administrative role?

2. What do they believe are the administrative competencies necessary to fulfill their role?

3. What role related strains, conflicts, and work overload do these nurse administrators identify?

4. What strategies do they use to cope with role strains, conflicts, and work overload?

5. What do they anticipate as their future ad- 
ministrative career pattern based on their experience to date as first-line administrators?

A random sample of 42 schools was drawn from the 114 nursing schools throughout the nation that were accredited by the National League for Nursing at the time, and that offered bachelor's degree and graduate nursing programs. The sample was stratified by geographic area and source of funding (public or private). The rationale for using these schools was that there was a high probability they differentiated top-, mid-, and first-level administrative roles due to the size of the student population and the programs offered. This rationale was validated during the research project.

A letter describing the study was sent to the dean or director of the 42 schools, requesting them to provide the names of the first-line administrators in their schools. Of these 42 schools, 29 deans and directors (69\%) responded from 24 different states. There were 22 state-supported and 7 private schools represented. The names of 90 first-line administrators were submitted who were subsequently sent a letter describing the study and inviting them to participate. Of the 90 administrators, $56(60 \%)$ agreed to participate in the study. Reasons for nonparticipation clustered into two categories: (1) The administrators were (a) leaving their first-line position to return to a full-time faculty role, (b) leaving the nursing school altogether, or (c) considering leaving their administrative position shortly; and (2) time constraints prohibited participation, such as (a) previously planned sabbatical leave, (b) varied commitments that would take considerable time, and (c) overextension due to research.

A demographic data collection instrument was mailed to participants for them to complete and return. Information was collected about the first-line administrators' (1) educational preparation, (2) academic rank, (3) title, (4) tenure status, (5) type and length of appointment, (6) positions and length of time as a nurse educator and administrator, (7) whether they were elected or appointed to their current position (if appointed, by whom), (8) type of educational institution in which they worked including specific information about the size of the faculty and student body, (9) usual teaching assignment, (10) publications during the past 5 years, and (11) age.

A guide was developed to use during telephone interviews with the first-line administrators. The guide contained nine questions that focused on the participants' past administrative positions in service and in academe; current administrative responsibilities; formal and informal administrative education, role preparation, and orientation; strains, conflicts, and work overload they experienced in their current position, and the strategies they used to cope; anticipated career in administration, based on their experience to date; the emphasis their institution placed on research and scholarship, teaching, and service; current research and scholarship efforts; and current clinical and/or professional practice and service activities.

During the telephone interviews, the researchers wrote down the participants' responses to each question, and these data were computerized subsequently to facilitate data management and analysis. Interrater reliability was established by one researcher who on preselected days and times monitored telephone interviews between the other researcher and participants, followed by a review of the written responses (Miles \& Huberman, 1984). The participants gave their permission for this reliability protocol before their telephone interview. The reliability coefficient was 94 .

A third instrument, illustrated in Fig 1, was used to collect data about the competencies a first-line nurse administrator in academe needs to have to fulfill job-related responsibilities. The instrument was adapted from Jennerich's study reported in 1981, in which he investigated the competencies that first-line administrators in academe believed were necessary to fulfill their job-related responsibilities. Jennerich collected data from 300 nonnurse participants who ranked the competencies in order of importance. In both the Jennerich and this research project, each of the 14 competencies was defined in writing, and the participants were asked to refer to the definitions when ranking the competencies.

\section{Results and Discussion}

The following composite description of a first-line educational administrator in a nursing school is based on the data collected.

The administrator, who is most commonly known as a departmental chairperson, is a 49-year-old woman who holds a ductor of philosuphy degree in a discipline other than nursing. Before her current position, she worked about 6 years in some type of a nursing service or academic administrative position. She is a tenured associate professor, has a 12-month appointment at a state-supported institution, and has worked 16 years as a nurse educator (but only for 3 years in her present administrative position). Her school emphasizes research and scholarship over teaching and service. 


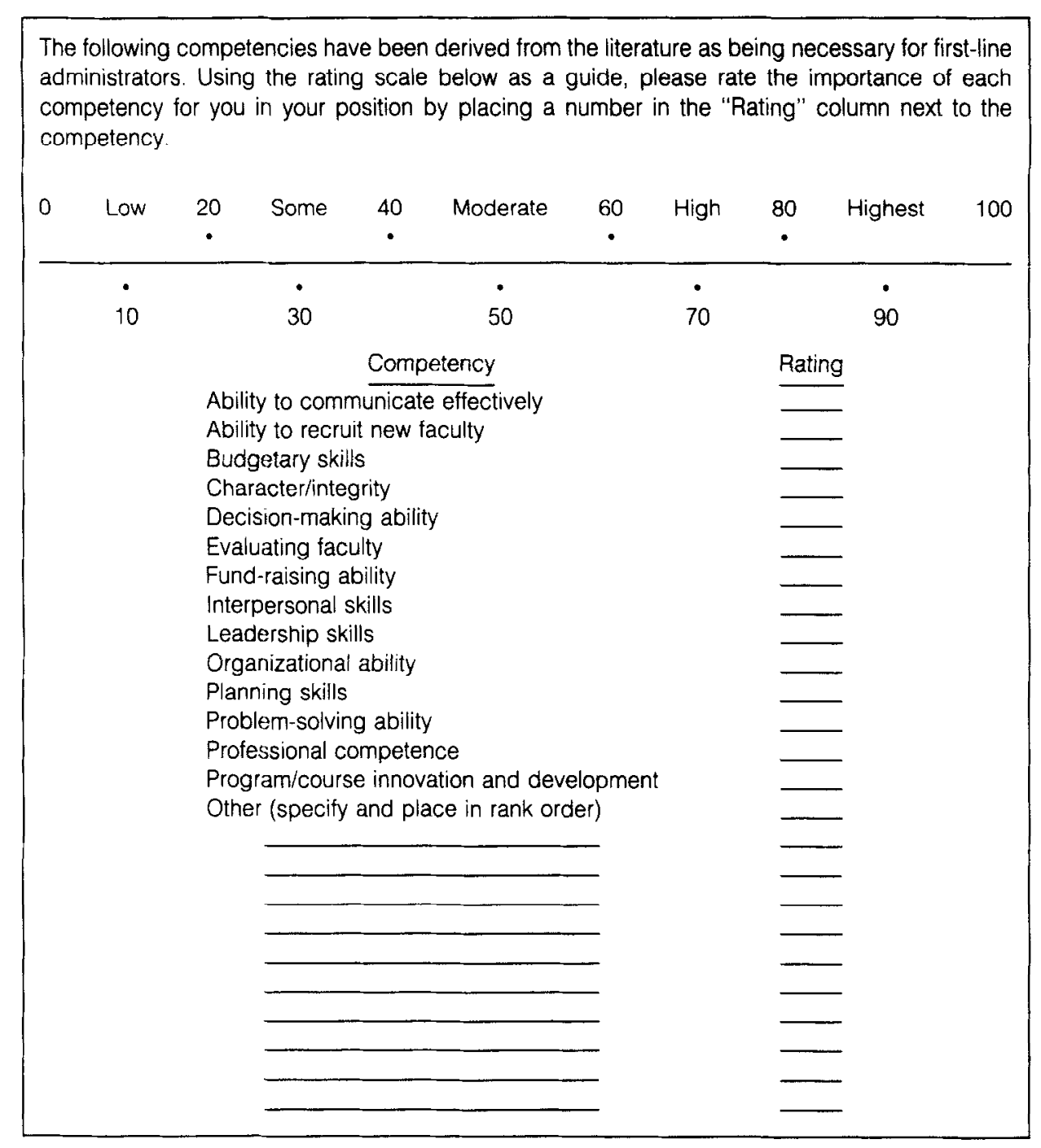

Figure 1. Competencies instrument. Adapted and reprinted with permission. An earlier version of this scale appeared in Edward $\mathbf{J}$. Jennerich, "Competencies for Department Chairpersons: Myths and Realities," Liberal Education 67, 1 (Spring 1981): 62, published by the Association of American Colleges.)

There are 16 full-time faculty in her department who serve approximately 145 undergraduate and 70 graduate students. She solo teaches two master's degree level courses each academic year. She is conducting research, and is engaged in professional practice primarily as a consultant to professional organizations and service institutions. This administrator does not work clinically. She is involved in numerous service activities through her membership on departmental, school, and university committees. During the past 5 years she published five articles in refereed journals and two in nonrefereed journals, a research abstract, and a chapter in a book.

By far the majority of her time and energy are spent on faculty-related responsibilities such as recruitment and hiring, negotiating teaching responsibilities, faculty development, and faculty evaluation. The firstline administrator in nursing also serves faculty as a consultant, problem solver, mentor, and "sounding board."

This administrator's other area of greatest respon- sibility is developing and managing the departmental budget where she allocates and monitors financial and material resources excluding fund-raising. Orher responsibilities of lesser import include curricular development, implemention, and evaluation; student issues related to recruitment, admission, orientation, progression, counseling, and problem-solving; and general governance of the nursing unit and the broader university by service on committees and community relations work. The generation of training grants and grants management is a minor part of this administrator's work, as is the supervision of support staff employed in her department.

With regard to the first research question regarding formal and informal role preparation, Table 1 summarizes the participants' formal educational preparation. Thirty-one of the 56 administrators interviewed completed graduate level administration courses after their graduate programs were completed; 4 were currently enrolled in graduate courses. In addition, continuing education conferences and workshops were 
TABLE 1. Educational Preparation of Study Participants

\begin{tabular}{|c|c|c|}
\hline Degree & Focus & Number \\
\hline $\mathrm{PhD}$ & $\begin{array}{l}\text { Nursing } \\
\text { Education } \\
\text { Higher education } \\
\text { Educational psychology } \\
\text { Unidentified, sociology } \\
\text { epidemiology, physiology, } \\
\text { organizational psychology, } \\
\text { multidisciplinary, home } \\
\text { economics, business and } \\
\text { health administration, } \\
\text { educational administration, } \\
\text { health science, } \\
\text { anthropology, psychology, } \\
\text { human development (one } \\
\text { in each area) }\end{array}$ & $\begin{array}{r}10 \\
6 \\
4 \\
3\end{array}$ \\
\hline DNS/DNSc & Nursing & 3 \\
\hline EdD & $\begin{array}{l}\text { Education } \\
\text { Higher educational } \\
\text { administration } \\
\text { Adult continuing education }\end{array}$ & $\begin{array}{l}3 \\
1\end{array}$ \\
\hline $\begin{array}{l}\text { DrPH } \\
\text { Subtotal, doctoral } \\
\text { preparation }\end{array}$ & Public health & $\begin{array}{r}1 \\
48\end{array}$ \\
\hline MS/MSN/MA & $\begin{array}{l}\text { Nursing } \\
\text { Psychiatric nursing }\end{array}$ & $\begin{array}{l}4 \\
2\end{array}$ \\
\hline $\begin{array}{l}\text { MPH } \\
\text { Subtotal, master's } \\
\text { degree } \\
\text { preparation }\end{array}$ & Public health & 2 \\
\hline Total & & 56 \\
\hline
\end{tabular}

cited by 27 administrators as informal means by which they prepared for their role. Eight stated they had $n o$ formal or informal educational preparation for their role.

Of the 56 nurse administrators, 26 also reported they had "on-the-job" training with a dean, with another administrator, or with an administrative peer; 29 discussed mentoring and independent study as ways they prepared for their administrative role.

The first-line administrators completed the Competencies Instrument described previously, which provided data to answer the second research question on administrative competency. Nurse administrators ranked the importance of the 14 administrative competencies, and these rankings are compared with Jennerich's (1981) findings (Table 2). A " 1 " indicates the most important competency; "14" indicates the least important. Cronbach's alpha for the instrument was .83 . The rank correlation coefficient was .89 indicating that the rankings of the competencies by nonnurse and nurse chairpersons were highly correlated.

Both the nurse and nonnurse participants ranked character and integrity as the most important administrative competency. These terms were defined as being trusted by the faculty, other administrators, and students. Fund-raising was ranked as the least important competency by both groups of participants.

First-line nurse administrators viewed leadership skills as much less important than their nonnurse counterparts. Leadership skills were defined as the ability and readiness to inspire, guide, direct and manage others in teaching and research in order to meet goals and to communicate these goals internally and externally.

The other area of greatest discrepancy between nurse and nonnurse administrators was their ranking of the importance of problem-solving ability, defined as the ability to find the correct solution or solutions to problem situations. Nurses viewed this competency as considerably more important than nonnurse administrators.

One can only conjecture as to why differences occurred in ranking these latter two competencies. Do first-line nurse administrators view nursing school faculty as more self-directed and less in need of what is traditionally defined as leadership? Or is it that these nurse administrators do not see themselves as leaders or needing to lead? Do nurse administrators view problem-solving abilities as more important because they have been educated since the beginning of their nursing career within a problem-solving paradigm? Or do these administrators in fact have more problems to solve than their nonnurse counterparts? If the latter is true, is this factor related to nursing as a practice profession as well as nursing as a discipline? Clearly, more research is needed in these areas as pursuit of these findings may be very revealing.

A final comment in relation to the Competencies Instrument: It should be remembered that during

TABLE 2. Rankings of the Importance of 14 Administrative Competencies

\begin{tabular}{lccc}
\hline \multicolumn{1}{c}{ Competency } & $\begin{array}{c}\text { Jennerich } \\
\text { Research }\end{array}$ & $\begin{array}{c}\text { Princeton } \\
\text { Research }\end{array}$ & Difference \\
\hline Character/integrity & 1 & 1 & 0 \\
Leadership skills & 2 & 6.5 & -4.5 \\
Interpersonal skills & 3 & 2 & 1 \\
Communication skills & 4 & 3 & 1 \\
Decision making & 5 & 4.5 & .5 \\
Organizational & & & \\
$\quad$ abilities & 6 & 6.5 & -.5 \\
Planning skills & 7 & 8 & -1 \\
Professionally & & & \\
$\quad$ competent & 8 & 9.5 & -1.5 \\
Problem solving & 9 & 4.5 & 4.5 \\
Evaluate faculty & 10 & 9.5 & 5 \\
Program/curricular & & & \\
$\quad$ development & 11 & 11 & 0 \\
Budgetary skills & 12 & 13 & -1 \\
Faculty recruitment & 13 & 12 & 1 \\
Fund-raising & 14 & 14 & 0 \\
\hline
\end{tabular}


telephone interviews, participants reported their second greatest responsibility was developing and managing the departmental budget in the form of allocating and monitoring financial and material resources. However, they ranked Budgetary Skills competency next to the lowest in importance. These results beg the question about the participants' interpretation of the terms "responsibility" and "competency." Thus, implications and conclusions about the meaning of these conflicting data are premature, and further studies in this area are called for.

In relation to the third research question, role strain was defined as any situation in which an individual experiences difficulty, pressure, or tension when fulfilling a role (Hardy, 1978). By far, their administrative work caused the greatest strain among these nurses. Examples included their continuous need to prioritize and reprioritize their administrative work, the extraordinary time needed to complete the vast amount of work confronting them, the continuous push to meet deadlines, and communication and "power play problems" with superiors.

The second area of greatest strain addressed by firstline administrators was in relation to the faculty in their unit with whom they worked directly. As examples, the administrators cited faculty conflicts, evaluation of faculty, faculty's hidden agendas that negatively influenced communications, workload problems, and the demanding and time-consuming orientation and development work with junior faculty.

Role conflict was defined as any situation in which an individual is confronted with competing expectations (Hardy, 1978). Of the 56 interviewees, 35 were tenured and 21 were not tenured. Regardless of their tenure status, the theme that permeated their responses was the conflict they experienced between the expectations inherent in their faculty role as a researcher and scholar, teacher, and service provider, and the demanding work associated with their academic administrative role. The conflict is compounded by the fact that their administrative work is not rewarded by institutions of higher education on equal terms with research, scholarship, and teaching, and certainly is not rewarded monitarily; administration is simply an "add on" responsibility, the administrators claimed.

Work overload was defined as the feeling of being overwhelmed when an attempt is made to balance multiple roles (Hardy, 1978). Following are selected quotations that express the administrators' thoughts and feelings about their work overload: "A completely crazy job-Overload is a prime problem." "This level administrative role is overwhelming." "I have total work overload-Research suffers." "Too much to do with too little time." "Overload occurs daily, as I try to merge scholarship, research, teaching, and administration." "A lot of work overload-A major problem." "Overload is constant, with little time for research." "My own needs are given a back seat to organizational needs." "There's little time for a scholarly role." "Verbal and written communications are overwhelm ing." "There is not enough time to do everything (research and scholarship, teaching, service, and administration)."

\section{... the theme that permeated their responses was ... . conflict}

The first-line nurse administrators' responses to the fourth research question-what they do to cope with role strains, conflicts, and overload-clustered into four categories: (1) management of time, (2) use of professional and personal support sysrems, (3) alteration of work style, and (4) rest and relaxation.

Some managed their time by leaving work early, working at home, attending conferences, and taking short vacations that they may not account for to their immediate supervisor. Others gave up clinical practice, and many claimed they decreased their efforts with research and scholarship, and service activities. One administrator stated she "ignores her mail," while others discussed how they "severely limited their open-door" office policy.

They used professional colleagues to help them cope by discussing their questions, concerns, and frustrations, and to help them problem-solve. These support systems included faculty and other first-line administrators within and outside their school, and when appropriate, graduate students and staff. They also used personal support systems, such as spouses and significant others, family members, and friends as "sounding boards" and as "caring others who would listen to problems and concerns."

Most administrators altered their work style by learning to use a computer to facilitate their work output, by increasing the amount of work they delegated to others, by withdrawing more quickly than they did previously from situations that seem unresolvable, and by learning to say "no." They learned to feel comfortable about not completing some work on time, and they learned to be comfortable with a higher level of ambiguity than ever before tolerated. 
As several participants stated, "We just can't have all the answers we want or need."

Just as importantly, they learned to take time for rest and relaxation: to play musical instruments, vacation, paint, cook, read, jog, exercise, meditate, and spend precious time with their loved ones.

Finally, in relation to the last research question regarding future administrative career patterns, what do these first-line administrators envision as their career pattern in administration based on their experiences to date? Twenty-one wanted to continue in their first-line role, and perhaps in time move to higher levels; 26 will not continue due to work-related strains, conflicts, and overload; 5 were not sure about their career pathway; and 4 will not continue due to retirement.

\section{Implications}

Debates need to be initiated among academic nurse administrators at all levels about strategies that will enable people in first-line positions to meet the necessary academic requirements for scholarship and re- search, teaching, and service in conjunction with their administrative role in order to decrease the stress that occurs when trying to satisfy all these demanding activities within a given time frame. Inherent in this debate is the issue of whether faculty should be tenured, or on a tenure or nontenure tract, when they are appointed to a first-line position.

It is unproductive to discuss other implicationssuch as how to retain first-line administrators in their positions, graduate programs and curricula that will prepare these administrators, job-related competencies that are needed, or the need for professional networking, etc-wirhout first resolving the "career drag" and role stress problems that result when these administrators overextend their personal resources. The implications loom large for reappointment, promotion, and tenure protocols to be revised, or devised as the case may be, so that administrative efforts are valued, recognized, and rewarded appropriately in relation to the traditional triad of faculty responsibilities.

Until basic issues are resolved, there will continue to be an administrative brain drain in academic nursing, with all of the associated problems.

\section{References}

Arminger, B. (1976). The educational crisis in the preparation of deans. Nursing Outlook, 24, 164-173.

Baker, C. (1979). Role conflicts of middle managers in baccalaureate and higher degree nursing programs in the United States. In Power: Nursing's challenge for change (pp. 147-159). ANA Publication G-135 SM. Kansas City, MO: American Nurses' Association.

Baker, C. (1981). The development of academic departments and governance in colleges of nursing. In J. C. McCloskey \& H. K. Grace (Eds.), Current issues in nursing. Boston: Blackwell Scientific.

Bergeron, R. M. (1963). The nursing departmental chairman in liberal arts colleges. Washington, D.C.: Catholic University of American Press.

Biglan, A. (1973). The characteristics of subject matter in different academic areas. Journal of Applied Psychology, 57, 195-203.

Branch, C. M. \& Hammons, J. (1985). Determining workload of department/division chairpersons. Community College Review, 3, 28-30.

Booth, D. (1972). Some reflections for prospective chairmen of academic units. In J. Brann \& T. A. Emmett (Eds.), The academic department or division chairman: A complex role (p. 73). Detroit: Balamp.

Carpenter, K. D. (1989). Academic middle managers for baccalaureate nursing: Work motivation and satisfaction. Journal of Nursing Education, 28, 256-264.

Cashin, W. E., \& Akihiro, N. (1986). Proceedings of Academic chairpersons: Unraveling the paradox. Kansas City: Kansas State University.

Dill, D. D., \& Fullagar, P. K. (1987). Leadership and administrative style. In M. W. Peterson (Ed.), Key resources on bigher education governance: Management and leadersbip. San Francisco: Jossey-Bass.

Dilly, F. B. (1972). The department chairman as academic planner. In J. Brann \& T. A. Emmett (Eds.), The academic department of division chairman: $A$ complex role (pp. 28-36). Detroit: Balamp.

Ehrle, E. B. (1975). Selection and evaluation of department chairmen. Educational Record, 56, 29.

Fain, J. A. (1987). Perceived role conflict, role ambiguity and job satisfaction among nurse educators. Journal of Nursing Education, 26, 233-238.

Falk, G. (1979). The academic department chairmanship and role conflict. Improving College and University Teaching, 27, 2.

Frank, B. (1986). The dean's job satisfaction: It's relationship to organizational structure. Journal of Nursing $E d-$ ucation, $25,59-63$

George, S. (1981). Associate and assistant deanships in schools of nursing. Nursing Leadership, 4, 25-30.

George, S. A., \& Coudret, N. A. (1986). Dynamics and dilemmas of the associate and assistant dean roles. Journal of Professional Nursing, 2, 173-179.

George, S., \& Deets, C. (1983). Top academic nurse administrators' perceptions of essential behaviors for their positions. Nursing Leadersbip, 6, 44-55.

Hall, B., McKay, R., \& Mitsunaga, B. (1971). Dimensions of role commitment: A study of career patterns of deans in nursing. Community Nursing Research, 3, 84-98.

Hall, B., Mitsunaga, B., \& de Tornyay, R. (1981). 
Deans of nursing: Changing socialization patterns. Nursing Outlook, 29, 92-95.

Hammons, J. (1984). The department/division chairperson: Educational leader? Community Junior College Journal, 3, 14-19.

Hardy, M.E. (1978). Role stress and role strain: In M. E. Hardy \& M. E. Conway (Eds.), Role theory: Perspectives for bealth professionals. Norwalk, CT: AppletonCentury-Crofts.

Hawkins, P. L. (1980). Growing our own: A way to prepare deans. Nursing Outlook, 3, 170-172.

Heimler, C. H. (1967). The college department chairman. Educational Record, 48, 158.

Holcomb, J. D. (1988). A follow-up study of the RN graduates of allied health education and administration doctoral programs. Journal of Profersional Nursing, 4, 131135.

Hoy, W. K., \& Miskel, C. G. (1987). Educational administration: Theory, research, and practice. New York: Random House.

Jarratt, V. (1975). The decanal role in the enhancement of educational institutions. In U.S. Department of Health, Education, and Welfare, The decanal role in baccalaureate and bigher degree colleges of nursing (Vol. 75, pp 13-24). Washington, D.C.: Author.

Jennerich, E. J. (1981). Comperencies for department chairpersons: Myths and realities. Liberal Education, 67, 40-70.

Johnson, B. M. (1983). The dean of nursing: A descriptive study with comparisons between nursing and social work deans. Washington, D.C.: American Association of Colleges of Nursing.

Kennerly, S. M. (1989). Leadership behavior and orga- nization characteristics: Implications for faculty satisfaction Journal of Nursing Education, 28, 198-202.

McKeachie, W. (1968). Memo to new department chairmen. Educational Record, 49, 221.

Miles, M. B., \& Huberman, A. M. (1984). Qualitative data analysis: A sourcebook of new metbods. Beverly Hills: Sage.

Monson, C. H. (1972). The University of Utah's department chairman training program. In J. Brann \& $T$. A. Emmett (Eds.), The academic department or division chairman: A complex role (pp. 37-42). Detroit: Balamp.

Ort, C. M. B. (1977). Middle managers in baccalaureate and bigher degree nursing programs: A study of the department chairperson's role. Unpublished doctoral dissertation, Columbia University, New York.

Schein, E. H. (1987). The art of managing buman resources. New York: Oxford University Press.

Scott, R. A. (1981). The department chairperson role, function, and future. In NLN Publication 23, pp. 1-14. New York: National League for Nursing.

Skoheim, R. A. (1981). Reflections upon academic administrative life. Liberal Education, 67, 1-9.

Smith, A. B. (1972). Department chairmen: Neither fish nor fowl. The Junior College Journal, 142, 40-43.

Tucker, A. (1984). Chairing the academic department. Leadership among peers (pp. 48-61). Washington, D.C.: The American Council on Education.

Waggman, J. S. (1984). Developmental programs for academic administrators: Considerations and outcomes. Administrative Update, 5, 1-5.

Zehr, S. (1974). The nursing deanship: A functional role analysis with implications for decanal role preparation. Unpublished doctoral dissertation. University of Minnesota, Minneapolis. 